\title{
A SURVEY ON KNOWLEDGE AND ATTITUDE TOWARDS LABOUR ANALGESIA AMONG PREGNANT WOMEN ATTENDING ANTENATAL CLINIC
}

\author{
Shareena T1, Syed Fazal Mahmood², S. Padmanabha ${ }^{3}$, Nidhin ${ }^{4}$ \\ ${ }^{1}$ Post Graduate Trainee, Department of Anaesthesia, Yenepoya Medical College, Mangalore. \\ ${ }^{2}$ Post Graduate Trainee, Department of Anaesthesia, Yenepoya Medical College, Mangalore. \\ 3 Professor and HOD, Department of Anaesthesia, Yenepoya Medical College, Mangalore. \\ ${ }^{4}$ Post Graduate Trainee, Department of Anaesthesia, Yenepoya Medical College, Mangalore.
}

\begin{abstract}
Services for labour pain relief are available in most of the centers. The number of patients who demand labour analgesia is remarkably low. The aim of this study was to find out the awareness and attitude of pregnant women towards labour analgesia.

\section{METHODOLOGY}

One thirty five pregnant women attending the antenatal clinic of Yenepoya Medical College were approached and those who volunteer to take part in the study were interviewed using a questionnaire that determined their knowledge and attitudes regarding labour analgesia.

\section{RESULTS}

Majority of the participants, $63.7 \%$ of them belonged to the rural area. Most of them had no idea about labour analgesia, but all the participants expressed their interest to learn about the technique and its advantages. Level of acceptance of labour analgesia after full information was found to be inadequate.
\end{abstract}

\section{CONCLUSION}

Most of the participants suffer from agony of labour pains due to lack of proper knowledge and awareness. The awareness level needs to be improved about the availability of the labour analgesia service.

\section{KEYWORDS}

Labour analgesia, Labour pain, Survey, Pregnancy.

HOW TO CITE THIS ARTICLE: Shareena T, Mahmood SF, S. Padmanabha, et al. "A survey on knowledge and attitude towards labour analgesia among pregnant women attending antenatal clinic". Journal of Evolution of Medical and Dental Sciences 2015;

Vol. 4, Issue 104, December 28; Page: 16909-16911, DOI: 10.14260/jemds/2015/2545

\section{INTRODUCTION}

Labour pain is one of the most severe pains that women experience during their life. Lack of knowledge regarding birth process can influence a woman's attitude to pain relief. Pain relief management during labour has undergone various advancement since 1847, when Simpson found that chloroform could help relieve the pain during the labour. ${ }^{1}$ Many pharmacological and non-pharmacological methods have been developed to alleviate the labour pains. Epidural analgesia is the technique capable of relieving labour pain satisfactorily and is the most effective method for restoration of normal uterine activity. ${ }^{2}$ The patients do not demand for it and the obstetricians are not keen to routinely practise it for several reasons. The important reasons are paucity of qualified anaesthesiologists and budgetary constraints. The existing attitudes and knowledge of obstetricians regarding labour analgesia, emphasized the need for better coordination and communication between the triad of obstetricians, anesthesiologists and patients. ${ }^{3}$ This study was designed to assess the pregnant women's knowledge of pain relief during labour and their beliefs, fears, source of information and misconceptions regarding epidural labour analgesia.

\section{METHOLOGY}

This study was conducted at Yenepoya Medical College, Mangalore city of South India. After obtaining ethical committee clearance, the work was started. One hundred and thirty five pregnant women attending the Antenatal Clinic of Yenepoya Medical College were approached and those who volunteer to take part in the study were given a set of questionnaire. Each pregnant woman was asked to mention their name, age, sex, gestational age, education and then were asked to answer the questionnaire. Each set of questionnaire had twenty one multiple choice questions. Each woman was asked to mark (Encircle) the most appropriate answer. Questions were taken from a study conducted previously by Shidhaye et al. all questions are designed to evaluate the knowledge and attitude towards labor analgesia. ${ }^{1}$

\section{RESULTS}

One hundred and thirty five pregnant patients attending Antenatal Clinic who were willing to participate in the survey were given a set of questionnaire.

Financial or Other, Competing Interest: None.

Submission 07-12-2015, Peer Review 08-12-2015,

Acceptance 23-12-2015, Published 26-12-2015.

Corresponding Author:

Dr. Syed Fazal Mahmood,

Department of Anaesthesia,

Yenepoya Medical College,

Mangalore.

E-mail: lazaf4u@gmail.com

DOI:10.14260/jemds/2015/2545 


\begin{tabular}{|c|c|c|c|}
\hline & & Frequency & Percent \\
\hline \multirow{3}{*}{ Address } & Rural & 86 & 63.7 \\
\hline & Semi urban & 37 & 27.4 \\
\hline & Urban & 12 & 8.9 \\
\hline \multirow{5}{*}{ Education } & $\begin{array}{c}\text { Can read and } \\
\text { write }\end{array}$ & 2 & 1.5 \\
\hline & $10^{\text {th }}$ & 40 & 29.6 \\
\hline & $12^{\text {th }}$ & 48 & 35.6 \\
\hline & Graduate & 39 & 28.9 \\
\hline & $\begin{array}{c}\text { Post } \\
\text { graduate }\end{array}$ & 6 & 4.4 \\
\hline \multirow{3}{*}{ Income } & & & \\
\hline & $1000-10000$ & $\begin{array}{l}97 \\
31\end{array}$ & $\begin{array}{l}71.9 \\
23.0\end{array}$ \\
\hline & $\begin{array}{l}10000- \\
50000\end{array}$ & 7 & 5.2 \\
\hline \multirow{5}{*}{ Gravid } & Primi & 7 & 5.2 \\
\hline & Second & 86 & 63.7 \\
\hline & Third & 33 & 24.4 \\
\hline & Fourth & 6 & 4.4 \\
\hline & More than 4 & 3 & 2.2 \\
\hline \multirow{3}{*}{$\begin{array}{c}\text { Duration of last } \\
\text { delivery }\end{array}$} & $\begin{array}{l}\text { No prior } \\
\text { delivery }\end{array}$ & 7 & 5.2 \\
\hline & Four-twelve & 122 & 90.4 \\
\hline & $\begin{array}{l}\text { Twelve - } \\
\text { eighteen }\end{array}$ & 6 & 4.4 \\
\hline \multirow{4}{*}{$\begin{array}{l}\text { Perception of } \\
\text { intensity of } \\
\text { labour pains }\end{array}$} & Moderate & 5 & 3.7 \\
\hline & Severe & 39 & 28.9 \\
\hline & Excruciating & 90 & 66.7 \\
\hline & $\begin{array}{c}\text { Excruciating } \\
\text { n unbearable }\end{array}$ & 1 & .7 \\
\hline & & & \\
\hline \multirow{5}{*}{$\begin{array}{c}\text { Fear of delivery } \\
\text { complications }\end{array}$} & Mild & 6 & 4.4 \\
\hline & Moderate & 95 & 70.4 \\
\hline & Much & 10 & 7.4 \\
\hline & Not at al & 3 & 2.2 \\
\hline & Very much & 21 & 15.6 \\
\hline \multirow{3}{*}{$\begin{array}{c}\text { Fear of labour } \\
\text { pains }\end{array}$} & Moderate & 12 & 8.9 \\
\hline & Much & 3 & 2.2 \\
\hline & Very much & 120 & 88.9 \\
\hline \multirow{3}{*}{$\begin{array}{c}\text { Is delivery } \\
\text { possible without } \\
\text { pains }\end{array}$} & Don't know & 81 & 60.0 \\
\hline & No & 26 & 19.3 \\
\hline & Yes & 28 & 20.7 \\
\hline \multirow{2}{*}{$\begin{array}{c}\text { Do } u \\
\text { hvinformtionabt } \\
\text { LA? }\end{array}$} & Littie bit & 28 & 20.7 \\
\hline & Not at all & 107 & 79.3 \\
\hline \multirow{4}{*}{$\begin{array}{l}\text { What is the } \\
\text { source of your } \\
\text { information? }\end{array}$} & Blank & 107 & 79.3 \\
\hline & Doctor & 6 & 4.4 \\
\hline & Neibourer & 6 & 4.4 \\
\hline & Relatives & 16 & 11.9 \\
\hline \multirow{4}{*}{$\begin{array}{l}\text { Would you like } \\
\text { to deliver } \\
\text { without pains }\end{array}$} & Like & 53 & 39.3 \\
\hline & May like & 60 & 44.4 \\
\hline & Not at all & 16 & 11.9 \\
\hline & $\begin{array}{l}\text { Wants to } \\
\text { deliver } \\
\text { without } \\
\text { suffering }\end{array}$ & 6 & 4.4 \\
\hline
\end{tabular}

\begin{tabular}{|c|c|c|c|}
\hline & Labor pains & & \\
\hline $\begin{array}{c}\text { Are you ready to } \\
\text { listen the } \\
\text { information }\end{array}$ & Ready & 135 & 100.0 \\
\hline \multirow{3}{*}{$\begin{array}{c}\text { Are you ready } \\
\text { for epidural } \\
\text { labour } \\
\text { analgesia? }\end{array}$} & Not at all & 67 & 49.6 \\
\hline & Ready & 44 & 32.6 \\
\hline & $\begin{array}{c}\text { Ready to } \\
\text { some extent }\end{array}$ & 24 & 17.8 \\
\hline \multirow{2}{*}{$\begin{array}{l}\text { Are you ready to } \\
\text { spend some } \\
\text { amount }\end{array}$} & Not at all & 95 & 70.4 \\
\hline & $\begin{array}{c}\text { Ready to } \\
\text { some extent }\end{array}$ & 40 & 29.6 \\
\hline \multirow{2}{*}{$\begin{array}{l}\text { Are you ready } \\
\text { without } \\
\text { spending }\end{array}$} & No & 69 & 51.1 \\
\hline & Yes & 66 & 48.9 \\
\hline \multirow{3}{*}{$\begin{array}{l}\text { Reasons for } \\
\text { unwillingness }\end{array}$} & Blank & 67 & 49.6 \\
\hline & $\begin{array}{l}\text { Labour is } \\
\text { natural } \\
\text { process }\end{array}$ & 41 & 30.4 \\
\hline & $\begin{array}{c}\text { Not confident } \\
\text { of the } \\
\text { procedure }\end{array}$ & 27 & 20.0 \\
\hline \multirow{3}{*}{$\begin{array}{c}\text { Any other } \\
\text { woman, deliver } \\
\text { with labour } \\
\text { analgesia } \\
\end{array}$} & No & 115 & 85.1 \\
\hline & Yes & 20 & 14.8 \\
\hline & & & \\
\hline \multirow{3}{*}{$\begin{array}{c}\text { If yes, she } \\
\text { satisfied with } \\
\text { labour analgesia }\end{array}$} & Blank & 121 & 89.6 \\
\hline & $\begin{array}{c}\text { Fully } \\
\text { satisfied n } \\
\text { will like to } \\
\text { have epidural } \\
\text { in } \\
\text { subsequent } \\
\text { deliveries }\end{array}$ & 5 & 3.7 \\
\hline & Satisfied & 9 & 6.7 \\
\hline
\end{tabular}

Geographical distribution; most of them (63.7\%) were from rural areas; $27.4 \%$ of them were from semiurban areas and $8.9 \%$ from urban localities.

Level of literacy: most of the patients had literacy level upto higher secondary education $35.6 \%, 29.6 \%$ had completed their primary school education, $28.9 \%$ had completed their graduation, $1.5 \%$ of the participants were educated upto the level of reading and writing.

Socioeconomic status: $71.9 \%$ of them had income of less than 1000, 23\% had income between 1000-10000 and between $10000-50000$ belongs to $5.2 \%$.

Level of previous experience of labour pains: Primi gravidas were $5.2 \%$, second gravidas were $63.7 \%$, third gravidas were $24.4 \%$ and multi gravidas were $2.2 \%$. Of the patients who had previously experienced labour pains, $90.4 \%$ had a 12-18 hours duration of labour pain and 4.4\% had $12-18$ hours duration.

Intensity of labour pains: Of the patients who had previously experienced labour pains, excruciating pain was seen in $66.7 \%$, severe pain in $28.9 \%$, excruciating and unbearable pain in $7 \%$. Fear of labour pain: very much pain in $88.9 \%$, moderate pain in $8.9 \%$, much pain in $2.2 \%$.

Fear of delivery complications: $2.2 \%$ of patients had no fear of delivery complications where $4.4 \%$ had mild fear, $70.4 \%$ had moderate fear, $7.4 \%$ had much fear and $15.6 \%$ had very much fear. 
Awareness of labour analgesia: 79.3\% did not know whether the delivery is possible without pains. Only $20.7 \%$ knew that delivery is possible without pain and $79.3 \%$ had information about labour analgesia, got it from their neighbourhood, relatives and doctors; $20.7 \%$ had little bit information.

Attitude of the participants towards labour analgesia: when we asked whether they would like to deliver without labour pains were $39.3 \%$ liked it, $11.9 \%$ did not want any labour analgesia. All the participants were ready to listen to the information about labour analgesia. In that $32.6 \%$ were ready for labour analgesia, $17.8 \%$ were ready to some extent, $49.6 \%$ were not at all ready for epidural analgesia. $70.4 \%$ were not at all ready to spend money. $29.6 \%$ were ready to some extent. $48.9 \%$ were ready if it is done without spending money.

Reasons for unwillingness, $30.4 \%$ said that labour is a natural process, $20 \%$ women were not confident about the procedure; $14.8 \%$ had information about other women who delivered by epidural analgesia.

\section{DISCUSSION}

Labour pain is the unbearable pain that women experiences during her child birth. Uterine contractions, cervical dilatation and stretching of the lower uterine segment are responsible for pain during the first stage of labour. Viscera l afferent Ctype fibres accompanying the sympathetic nerves carry the pain impulses and enter the spinal cord at the T10-L1 levels. ${ }^{4}$ In the second stage of labour, somatic afferent fibres from the vagina and perineum convey the pain impulses in the pudendal nerves to the S2-S4 spinal nerve roots.

This pain can be relieved by labour analgesia. There are many methods to relieve labour pain, of which Epidural labour analgesia is the very effective pharmacological method to relieve the labour pain. ${ }^{5}$

In our study, most of the patients were from the rural area $(63.7 \%)$ and all of them could read and write, almost all the patients belonged to lower socioeconomic status where their income was less than Rs. 10000 per month, only $5.2 \%$ of the patients had income of more than Rs. 10000 per month.

Only 7 patients in this study were primigravidas and $90.4 \%$ of the patients admitted that the labour pains lasted 4 to 12 hours during their last experience; $66.7 \%$ of the patients had excruciating pain where remaining patients had moderate pains. A $15.6 \%$ of the patients admitted that they had very much fear about complications of labour; $88.9 \%$ of the patients had fear of labour pains.
A $60 \%$ of the patients did not know that delivery was possible without any pains, only $20.7 \%$ of the patients knew that the labour pain can be controlled; $39.3 \%$ of the patients wanted to deliver without any labour pains.

All the patients agreed to listen to the information about labour analgesia and after listening to the information about epidural labour analgesia; $32.6 \%$ of the patients agreed for epidural analgesia, $49.6 \%$ refused for epidural labour analgesia and $17.8 \%$ were in doubt if they have to undergo labour analgesia.

A $29.6 \%$ of the patients agreed to spend some amount on labour analgesia, but $48.9 \%$ agreed for labour analgesia if it was provided for free. Of the patients who were unwilling for labour analgesia, majorty of them told that labour is natural process and should be allowed to happen naturally; remaining patients were not confident about the procedure; $14.8 \%$ of the patients knew other women who delivered with labour analgesia and only $6.7 \%$ of the women were satisfied.

\section{CONCLUSION}

A total of 135 patients were studied and we conclude that awareness and knowledge regarding labour analgesia in study population was inadequate and even though few women who received information about what to expect during labour found the information useful, most of them expressed little confidence in labour pain relief.

\section{REFERENCES}

1. Shidhaye RV, Galande M, Bangal VB, et al. Awareness and attitude of Indian pregnant women towards labour analgesia, anaesth, pain \& intensive care, 2012;16(2):131136.

2. James JN, Prakash KS, Ponniah M. Awareness and attitudes towards labour pain and labour pain relief of urban women attending a private antenatal clinic in Chennai, India: Indian Journal of Anaesthesia 2012;56,2:195-198.

3. Ogboli-Nwasor E, Adaji SE, Bature SB, et al. Pain relief in labour: a survey of awareness, attitude and practice of health care providers in Zaria, Nigeria. Journal of Pain Research 2011;4:227-232.

4. Atiya Barakzai, Gulfareen Haider, Farhana Yousuf, et al. Awareness of women regarding analgesia during labour; J Ayub Med Coll Abbottabad 2010;22(1):73-75.

5. Mary T Nabukenya, Andrew Kintu, Agnes Wabule, et al. Knowledge, attitudes and use of labour analgesia among women at a low-income country antenatal clinic; BMC Anesthesiology 2015;15,98:1-6. 